\title{
*Effects of Deteriorated Frying Oil and Dietary Protein Levels on Liver Microsomal Enzymes in Rats
}

\author{
Ching-Jang Huang*, Nam-Sang Cheung and Ven-Rond Lu \\ Laboratory of Nutritional Chemistry, Department of Agricultural Chemistry, National Taiwan University, 1, Sec. 4, Roosevelt Rd., \\ Taipei, Taiwan, 10764 Republic of China
}

This study was conducted to investigate the effects of deteriorated used frying oil (DUFO) and dietary protein levels upon the hepatic microsomal drugmetabolizing enzyme system. Fresh soybean oil was subjected to a deep-frying process at $205 \pm 5^{\circ} \mathrm{C}$ for four six-hr periods. The resultant DUFO was incorporated into high protein (HU) (27\% lactalbumin) or low protein (LU) ( $8 \%$ lactalbumin) test diets at a $15 \%$ level. High protein (HF) and low protein (LF) diets containing fresh soybean oil served as the control. Male LongEvans young rats fed the test diets for eight weeks showed decreased fat absorption and increased red blood cell (RBC) in vitro hemolysis. The activities of hepatic aminopyrine $\mathrm{N}$-demethylase (AD), aniline hydroxylase (AH), NADPH-cytochrome C reductase (NCD), UDP-glucuronyl transferase (UDPGT) and glutathione S-transferase (GST) as well as cytochrome $P-450$ content were significantly increased in rats fed the HU diet. However, the AD, AH and GST activities, as well as the cytochrome $P-450$ content of the $L U$ group, were increased to a lesser extent and significantly lower than those of the HU group. Rats fed the LU diet were the only group that showed significantly elevated serum GOT (E.C. 2.6.1.1, glutamate-oxaloacetate transaminase) and GPT (E.C. 2.6.1.2, glutamatepyruvate transaminase) values. Supplementation of $0.3 \%$ DL-methionine to the HU diet further increased GST activity. Unexpectedly, rats fed the low protein control diet (LF) also had raised levels of $\mathrm{AD}, \mathrm{AH}$ and UDPGT activities as well as in vitro RBC hemolysis. It was concluded that rat hepatic microsomal enzymes are induced by dietary DUFO and that the level of induction is influenced by dietary protein level.

The nutritional and other biological effects of thermally oxidized fats have been studied and reviewed extensively (1-4). Appetite and growth depression, decreased fat absorption, and enlargement of the liver and kidney were the most common observations in long-term feeding studies. Liver enlargement frequently is accompanied by an increase in microsomal enzyme activities in animals dosed with xenobiotics. Andia and Street (5) observed an elevation of EPN(O-Ethyl O-p-nitrophenyl phenylphosphonothioate) oxidation, glucuronyl transferase and methyl transferase activities in rats fed thermally oxidized fats. However, they did not find significant change in the cytochrome $\mathbf{P}$. 450 content.

On the other hand, the toxicity of used frying oil was found to be less severe when rats were fed a diet of higher protein content $(6,7)$. This is in agreement with the observations that hepatic microsomal enzyme activities (8-11) and inducibility (12-14) are increased with dietary protein levels. Therefore, we proposed that the beneficial effect of a high protein diet on the toxicity of deteriorated oil is via a sufficient induction of hepatic microsomal enzymes to metabolize the lipid peroxidation products.

Xenobiotics, in addition to inducing hepatic microsomal drug-metabolizing enzymes, also significantly increase serum cholesterol and liver lipids (15). Methionine was shown to be effective in alleviating toxicity of used frying oil in a $27 \%$ casein diet (7). Because methionine is the first limiting amino acid of casein, the beneficial effect of methionine supplementation could be only "nutritional" and rather "pharmacological." Thus, in the present study, we analyzed the hepatic microsomal enzyme activities, plasma cholesterol, liver lipid and in vitro $\mathrm{RBC}$ hemolysis in rats fed a $15 \%$ deteriorated used frying oil diet which contained $27 \%$ or $8 \%$ lactalbumin with or without the supplementation of methionine.

\section{MATERIALS AND METHODS}

Preparation of deteriorated used frying oil (DUFO). Soybean oil ('Taiwan Sugar Co., Taipei, Taiwan) purchased from a local supermarket was subjected to the following frying process: $5.5 \mathrm{~kg}$ soybean oil was poured

TABLE 1

Changes in the Quality of Soybean Oil Used for Frying Dough Sheet for Four Consecutive Days $^{a}$

\begin{tabular}{ccccc}
$\begin{array}{c}\text { Frying } \\
\text { time } \\
(\mathbf{h r})\end{array}$ & $\begin{array}{c}\text { Viscosity }\left(25^{\circ} \mathrm{C}\right) \\
\text { (centipoises) }\end{array}$ & $\begin{array}{c}\text { UV233 } \mathrm{nm} \\
\text { (absorbance/g) }\end{array}$ & $\begin{array}{c}\text { Acid value } \\
\text { (mg of KOH/g) }\end{array}$ & $\begin{array}{c}\text { Peroxide value } \\
\text { (meq/Kg) }\end{array}$ \\
\hline 0 & 48 & 127 & 0.14 & 0.8 \\
6 & 70 & 1880 & 0.61 & 2.2 \\
12 & 103 & 2720 & 0.92 & 3.2 \\
18 & 158 & 3174 & 1.88 & 3.7 \\
24 & 285 & 3582 & 2.90 & 4.9
\end{tabular}

$a_{6 \mathrm{hr} / \text { day, }} 205 \pm 5^{\circ} \mathrm{C}$.

\footnotetext{
*To whom correspondence should be addressed.
} 
DETERIORATED OIL, DIETARY PROTEIN AND MICROSOMAL ENZYMES

TABLE 2

\begin{tabular}{|c|c|c|c|c|c|c|}
\hline Diet group & $\mathrm{HF}$ & $\mathrm{HU}$ & HFM & HUM & LF & $\mathrm{LU}$ \\
\hline lactalbumin $^{b}$ & 27 & 27 & 27 & 27 & 8 & 8 \\
\hline vitamin premix ${ }^{c}$ & 1 & 1 & 1 & 1 & 1 & 1 \\
\hline solka floc ${ }^{b}$ & 3 & 3 & 3 & 3 & 3 & 3 \\
\hline salt mixture ${ }^{d}$ & 4 & 4 & 4 & 4 & 4 & 4 \\
\hline corn $\operatorname{starch}^{b}$ & 50 & 50 & 49.7 & 49.7 & 69 & 69 \\
\hline fresh oil ${ }^{e}$ & 15 & - & 15 & - & 15 & - \\
\hline used oilf & - & 15 & - & 15 & - & 15 \\
\hline DL-methionine & - & - & 0.3 & 0.3 & - & - \\
\hline choline $\mathrm{HCl}$ & 0.3 & 0.3 & 0.3 & 0.3 & 0.3 & 0.3 \\
\hline
\end{tabular}

\footnotetext{
$a_{\mathrm{g} / 100 \mathrm{~g} \text { diet. }}$

${ }^{b}$ Lactalbumin, Sigma Chemical Co., St. Louis, Missouri; solka floc, cellulose product of Brown Co., Berlin, New Hampshire; corn starch, Roquette, France.

${ }^{c}$ Vitamin premix: Thiamin, $40 \mathrm{mg}$; riboflavin, $80 \mathrm{mg}$; vitamin $\mathrm{B}_{6}, 40 \mathrm{mg}$; vitamin $\mathrm{B}_{12}$, $0.3 \mathrm{mg}$; folic acid, $2 \mathrm{mg}$; niacin, $400 \mathrm{mg}$; PABA, 2,000 mg; inositol, 2,000 mg; Ca-pentothenate, $400 \mathrm{mg}$; menadione, $100 \mathrm{mg}$; biotin, $2 \mathrm{mg}$; $\alpha$-tocopheryl acetate, $200 \mathrm{mg}$; vitamin A, 17,000 IU; vitamin D, 12,000 IU; sucrose made up to $100 \mathrm{~g}$.

${ }^{d}$ Salt mixture: $\mathrm{CaCO}_{3}, 600 \mathrm{~g} ; \mathrm{K}_{2} \mathrm{HPO}_{4}, 625 \mathrm{~g} ; \mathrm{CaHPO}_{4} \bullet 2 \mathrm{H}_{2} \mathrm{O}, 150 \mathrm{~g} ; \mathrm{MgSO}_{4} \cdot 7 \mathrm{H}_{2} \mathrm{O}$, $205 \mathrm{~g}$; NaCl, $335 \mathrm{~g}$; Fe-citrate, $55 \mathrm{~g}$; $\mathrm{MnSO}_{4} \bullet 4 \mathrm{H}_{2} \mathrm{O}, 7.6 \mathrm{~g}$; KI, $1.6 \mathrm{~g} ; \mathrm{ZnCl}_{2}, 0.5 \mathrm{~g}$, and $\mathrm{CuSO}_{4} \cdot 5 \mathrm{H}_{2} \mathrm{O}, 0.38 \mathrm{~g}$.

${ }^{e}$ Fresh soybean oil, Taiwan Sugar Co., Taipei, Taiwan.

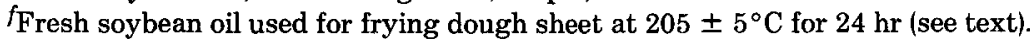

into a cast iron wok $(40 \mathrm{~cm}$ i.d., $10 \mathrm{~cm}$ central depth, 6.51 capacity) and heated on a gas stove which was adjusted to maintain the oil temperature within 205 $\pm 5^{\circ} \mathrm{C}$. Wheat flour dough sheets $(12 \times 4.5 \times 0.15 \mathrm{~cm}$, ca. $11 \mathrm{~g}$ in weight) were fried in the oil, one at a time. The wheat flour dough was made by mixing together $1500 \mathrm{~g}$ high gluten wheat flour, $200 \mathrm{~g}$ table sugar, $5 \mathrm{~g}$ baking powder and $600 \mathrm{~g}$ water. The frying proceeded for six hr/day and was repeated successively for four days. The resultant deteriorated used frying oil (DUFO) as well as the unfried fresh oil were stored at $-20^{\circ} \mathrm{C}$ for the preparation of test diets. The viscosity (Brookfield Synchro-Lectric Viscometer, Model RTV), acid value (16), absorbance at $233 \mathrm{~nm}$ (17) and peroxide value (16) of the oils were analyzed; results are shown in Table 1.

Animals and test diets. Male Long-Evans weanling rats (Lab. Animal Center, College of Medicine, National Taiwan University) were housed individually in stainless steel wire cages in a room maintained at $25 \pm 1{ }^{\circ} \mathrm{C}$ with a controlled 12 -hr light-dark cycle. For adaption, they were fed a stock diet (Lab. Rodent Chow, Ralston Purina co., St. Louis, Missouri) for one week prior to the experiment. The average body weight of these rats was $67.7 \pm 9.1 \mathrm{~g}$ after the adaption period. Water was supplied freely throughout the feeding.

Six diets were used in the experiment. They were: HU diet, high protein and DUFO diet; LU diet, low protein and DUFO diet; HF diet, high protein and fresh soybean oil diet; LF diet, low protein and fresh soybean oil diet, and HUM and HFM diets, methioninesupplemented HU and HF diets. These diet codes stand for the diet and the group of rats fed that diet. The compositions of these diets are shown in Table 2. The HU, HUM and LU diets contained 15\% DUFO. The other three (the HF, HFM and LF diets), containing $15 \%$ fresh soybean oil, served as controls. The remain- ing portion of the diets contained either $27 \%$ lactalbumin (the HU, HUM, HF and HFM diets) or $8 \%$ lactalbumin (the LU and LF diets) as well as other essential nutrients. The HUM and HFM diets were supplemented with $0.3 \%$ DL-Methionine. In preparing the test diets, the powder ingredients were mixed in advance, and the oil portion was blended in each week before feeding.

Forty-two rats were randomly divided into seven groups of six rats each. Each of six groups was fed one of the six test diets ad libitum. The remaining group was designated the P-HU group and given the HU diet in a restricted amount. The daily amount of diet given to this P-HU group was calculated by multiplying the mean food intake/body weight ratio of the LU group to the body weight of each rat in this group. Body weight and food intake were recorded weekly.

Determination of fat digestibility. On the sixth week of the experiment, rats were transferred into metabolic cages. Feces were collected for a one-week period and analyzed for crude fat content by ether extraction. Apparent fat digestibility was calculated from food intake and fecal fat excretion.

Tissue sampling and preparation. At the termination of eight weeks of feeding, the rats were killed with carbon dioxide between 8:30 and 9:30 a.m. on three successive days. Blood was drawn via heart puncture using heparinized evacuated blood-collecting tubes (Venoject, Terumo Corp., Tokyo, Japan). Livers were excised, weighed and immediately homogenized in a $0.01 \mathrm{M}$ phosphate buffer $(\mathrm{pH} 7.4$, containing $1.15 \% \mathrm{KCl})$ with a Potter-Elvehjem homogenizer. Aliquots of the crude homogenate $(25 \% \mathrm{w} / \mathrm{v})$ were centrifuged at 12,000 $\times \mathrm{g}$ for $20 \mathrm{~min}$ (20 PR-5 freeze centrifuge, RPR 18 rotor, Hitachi Co., Tokyo, Japan). Aliquots of the postmitochondria supernatant obtained were centrifuged at $105,000 \times \mathrm{g}$ for $60 \mathrm{~min}$ (Ultracentrifuge, RP55 ro- 
TABLE 3

Body Weight Gain, Food Intake, Feed Efficiency, Apparent Digestibility of Fat and Relative Liver Weight of Rats Fed $27 \%$ or $8 \%$ Lactalbumin Diet with Fresh or Used Oil for Eight Weeks ${ }^{a}$

\begin{tabular}{lcccccc}
\hline & $\begin{array}{c}\text { Final body } \\
\text { weight } \\
(\mathrm{g})\end{array}$ & $\begin{array}{c}\text { Body weight } \\
\text { gain } \\
(\mathrm{g})\end{array}$ & $\begin{array}{c}\text { Food intake } \\
(\mathrm{g} / 8 \text { weeks) }\end{array}$ & $\begin{array}{c}\text { Feed efficiency } \\
(\mathrm{BW} \text { gain/feed intake) }\end{array}$ & $\begin{array}{c}\text { Apparent } \\
\text { digestibility } \\
\text { of fat (\%) }\end{array}$ & $\begin{array}{c}\text { Relative liver } \\
\text { weight } \\
(\% \mathrm{BW})\end{array}$ \\
\hline HF & $354.0 \pm 25.9^{\mathrm{d}, \mathrm{e}}$ & $287.8 \pm 21.5^{\mathrm{d}, \mathrm{e}}$ & $878.3 \pm 69.4^{\mathrm{c}}$ & $0.33 \pm 0.024^{\mathrm{d}}$ & $95.8 \pm 1.9^{\mathrm{b}}$ & $3.3 \pm 0.22^{\mathrm{a}}$ \\
HU & $328.8 \pm 20.1^{\mathrm{c}}$ & $259.8 \pm 19.3^{\mathrm{c}, \mathrm{d}}$ & $880.7 \pm 49.0^{\mathrm{c}}$ & $0.30 \pm 0.033^{\mathrm{c}, \mathrm{d}}$ & $86.2 \pm 4.4^{\mathrm{a}}$ & $4.7 \pm 0.36^{\mathrm{b}}$ \\
HFM & $362.8 \pm 10.5^{\mathrm{e}}$ & $294.0 \pm 12.6^{\mathrm{e}}$ & $951.6 \pm 27.0^{\mathrm{c}}$ & $0.31 \pm 0.014^{\mathrm{c}, \mathrm{d}}$ & $94.3 \pm 2.1^{\mathrm{b}}$ & $3.3 \pm 0.23^{\mathrm{a}}$ \\
HUM & $323.3 \pm 174^{\mathrm{c}, \mathrm{d}}$ & $255.2 \pm 22.5^{\mathrm{c}}$ & $853.4 \pm 74.3^{\mathrm{c}}$ & $0.30 \pm 0.050^{\mathrm{c}, \mathrm{d}}$ & $87.8 \pm 4.5^{\mathrm{a}}$ & $4.9 \pm 0.22^{\mathrm{b}}$ \\
LF & $237.8 \pm 27.6^{\mathrm{b}}$ & $171.2 \pm 30.0^{\mathrm{b}}$ & $728.3 \pm 92.4^{\mathrm{b}}$ & $0.23 \pm 0.016^{\mathrm{b}}$ & $96.0 \pm 1.3^{\mathrm{b}}$ & $3.8 \pm 0.90^{\mathrm{a}}$ \\
LU & $157.2 \pm 31.0^{\mathrm{a}}$ & $89.7 \pm 28.5^{\mathrm{a}}$ & $469.9 \pm 93.5^{\mathrm{a}}$ & $0.19 \pm 0.040^{\mathrm{a}}$ & $86.5 \pm 2.4^{\mathrm{a}}$ & $5.1 \pm 0.95^{\mathrm{b}}$ \\
P-HU & $261.0 \pm 39.9^{\mathrm{b}}$ & $192.8 \pm 34.2^{\mathrm{b}}$ & $685.9 \pm 151.3^{\mathrm{b}}$ & $0.29 \pm 0.040^{\mathrm{c}}$ & $85.0 \pm 2.5^{\mathrm{a}}$ & $4.7 \pm 0.22^{\mathrm{b}}$ \\
\hline
\end{tabular}

${ }^{a}$ Each value represents the mean \pm S.D. of six rats.

Values not sharing common superscript letters are significantly different from one another by Duncan's Multiple Range Test $(\mathrm{P}<0.05)$.

tor, Hitachi Co., Tokyo, Japan). The microsomal pellets were suspended in $0.05 \mathrm{M}$ phosphate buffer $(\mathrm{pH}$ 7.7, containing $10^{-3} \mathrm{M}$ EDTA).

Analyses. Blood samples were analyzed for hematocrit by centrifugation in a capillary tube. An in vitro RBC hemolysis test was performed by incubating washed RBC with hydrogen peroxide (18). Plasma cholesterol was extracted by ethanol and determined colorimetrically with ferric chloride and sulfuric acid (19). Plasma triglyceride (20) as well as GOT (E.C. 2.6.1.1, glutamate-oxaloacetate transaminase) and GPT (E.C. 2.6.1.2, glutamate-pyruvate transaminase) activities (21) were determined using commercially available kits (BGH Biochemical Co., Taipei, Taiwan).

The post-mitochondria supernatants were assayed for the activities of aniline hydroxylase (AH), aminopyrine $\mathrm{N}$-demethylase (AD), UDP-glucuronyl transferase (UDPGT) and glutathione S-transferase (GST). The assay mixture of $\mathrm{AH}$ was as described by Kato and Yoshida (15), and p-aminophenol produced was measured (22). The assay mixture of $\mathrm{AD}$ was as reported by Kato et al. (12), and the HCHO released was measured (23). The assay of UDPGT was according to the method of Thurman et al. (24) using p-nitrophenol as substrate. The GST activity was determined as reported by Habig et al. (25) using p-nitrobenzyl chloride as substrate.

The NADPH-cytochrome $\mathrm{C}$ reductase activity and cytochrome P-450 content in microsomal suspension were determined by the methods of William and Kamin (26) and of Omura and Sato (27), respectively. The change in absorbance at $550 \mathrm{~nm}$ of reduced cytochrome $\mathrm{C}$ was measured in the assay of NADPH-cytochrome $\mathrm{C}$ reductase. Cytochrome P-450 was determined by the dithionite $\mathrm{CO}$ binding difference spectrum. Protein was quantified by the method of Lowry et al. (28) using bovine serum albumin as the standard. All enzyme activities were determined within the zero-order kinetic area on reaction curves. Except for GOT and GPT, the activities of the enzymes analyzed are all expressed in terms of the international unit (U), which is defined as $\mu \mathrm{mol}$ substrate decreased/min or $\mu \mathrm{mol}$ product increased/min in each of the assay systems. The specific activity (U/mg protein), tissue concentration of the enzyme activity (U/g liver) as well as the activity per unit body weight (U/100 g body weight) are all calculated. The plasma GOT and GPT activities are expressed in Sigma Frankel units (SF unit), which

TABLE 4

Blood Analysis of Rats Fed $27 \%$ or $8 \%$ Lactalbumin Diet with Fresh or Used Oil for Eight Weeks

\begin{tabular}{|c|c|c|c|c|c|c|}
\hline & $\begin{array}{c}\text { Plasma } \\
\text { cholesterol } \\
(\mathrm{mg} / 100 \mathrm{ml})\end{array}$ & $\begin{array}{c}\text { Plasma } \\
\text { triglyceride } \\
(\mathrm{mg} / 100 \mathrm{ml})\end{array}$ & $\begin{array}{c}\mathrm{GOT} \\
(\mathrm{SF} / \mathrm{ml})^{b}\end{array}$ & $\begin{array}{c}\mathrm{GPT} \\
(\mathrm{SF} / \mathrm{ml})^{b}\end{array}$ & $\begin{array}{c}\text { Hematocrit } \\
(\%)\end{array}$ & $\begin{array}{c}\text { In vitro RBC } \\
\text { Hemolysis } \\
(\%)\end{array}$ \\
\hline HF & $124.0 \pm 23.4^{a, b}$ & $59.3 \pm 21.0^{\mathrm{b}, \mathrm{c}}$ & $51.0 \pm 16.0^{\mathrm{a}}$ & $54.8 \pm 22.0^{\mathrm{a}}$ & $45.2 \pm 2.4^{c}$ & $7.6 \pm 5.7^{\mathrm{a}}$ \\
\hline $\mathrm{HU}$ & $105.0 \pm 5.6^{\mathrm{a}}$ & $36.8 \pm 9.4^{\mathrm{a}}$ & $48.1 \pm 9.5^{\mathrm{a}}$ & $62.3 \pm 20.2^{\mathrm{a}}$ & $41.2 \pm 1.7^{\mathrm{b}}$ & $66.1 \pm 6.7^{c}$ \\
\hline HFM & $124.0 \pm 30.3^{\mathrm{a}, \mathrm{b}}$ & $64.3 \pm 19.4^{\mathrm{c}, \mathrm{d}}$ & $55.7 \pm 15.0^{\mathrm{a}}$ & $48.8 \pm 15.7^{\mathrm{a}}$ & $45.2 \pm 2.3^{c}$ & $10.5 \pm 6.4^{\mathrm{a}}$ \\
\hline HUM & $107.0 \pm 32.5^{\mathrm{a}}$ & $37.8 \pm 7.6^{\mathrm{a}}$ & $59.6 \pm 1.3^{\mathrm{a}}$ & $58.4 \pm 14.9^{a}$ & $41.5 \pm 1.6^{b}$ & $75.5 \pm 4.9^{c, d}$ \\
\hline LF & $159.0 \pm 26.5^{b}$ & $90.0 \pm 15.5^{\mathrm{e}}$ & $52.2 \pm 12.0^{\mathrm{a}}$ & $48.7 \pm 10.2^{a}$ & $38.8 \pm 1.9^{b}$ & $40.6 \pm 9.4^{\mathrm{b}}$ \\
\hline $\mathrm{LU}$ & $134.0 \pm 23.8^{\mathrm{a}, \mathrm{b}}$ & $79.2 \pm 15.0^{\mathrm{d}, \mathrm{e}}$ & $77.0 \pm 9.8^{b}$ & $82.0 \pm 21.2^{b}$ & $34.2 \pm 3.9^{\mathrm{a}}$ & $64.0 \pm 5.5^{\mathrm{c}}$ \\
\hline P-HU & $119.0 \pm 22.5^{\mathrm{a}}$ & $46.2 \pm 6.7^{\mathrm{a}, \mathrm{b}}$ & $54.0 \pm 21.8^{a}$ & $49.0 \pm 18.3^{\mathrm{a}}$ & $39.8 \pm 1.7^{\mathrm{b}}$ & $84.5 \pm 1.3^{\mathrm{d}}$ \\
\hline
\end{tabular}

${ }^{a}$ Each value represents the mean \pm S.D. of six rats.

${ }^{b} \mathrm{SF}$, Sigma Frankel unit, is $4.82 \times 10^{-4} \mu \mathrm{mol}$ glutamate produced/min at $25 \mathrm{C}$ and $\mathrm{pH} 7.5$.

Values not sharing common superscript letters are significantly different from one another by Duncan's Multiple Range Test $(\mathrm{P}<0.05)$. 
are equivalent to the production of $4.82 \times 10^{-4} \mu \mathrm{mol}$ glutamate/min at $25^{\circ} \mathrm{C}$ under $\mathrm{pH} 7.5$.

A small portion from each rat liver (1-2 g) was extracted with methanol:chloroform (2:1) according to Folch's method (29). Aliquots of the extract were analyzed for cholesterol by Liebermann-Burchard reagent (30) and for triglyceride (20) using the commercial kit mentioned above.

Statistical analyses. The data are expressed as mean \pm S.D. for six rats in each group. The significance of difference among groups was analyzed statistically by Analysis of Variance (ANOVA) and Duncan's Multiple Range test using the "Oneway" Program in the SPSS Package (31).

\section{RESULTS}

No deaths occurred throughout the feeding of test diets in this study. Although mild diarrhea was observed during the first week of DUFO feeding, fecal excretion of these rats returned to normal from the second week on.

The results of body weight gain, food intake and feed efficiency are shown in Table 3 . In rats fed the high protein diet, the body weight gain of the HU group is $10 \%$ less than for the HF group. However, the growth of the LU group was severely depressed; the body weight gain of this group was only half that of the LF group. There was no significant difference between the feed efficiency of the HF and HU groups, but the feed efficiency of the LU group was significantly lower than that of the LF group. Compared with the fresh oil diet fed control groups, the apparent fat digestibility was lowered significantly in the DUFO fed groups (Table 3 ). The apparent fat digestibility was similar in all DUFO fed groups, and was not affected by dietary protein levels.

Data reporting blood and plasma analyses are shown in Table 4. Hematocrit values were decreased and in vitro $\mathrm{RBC}$ hemolysis was increased in rats fed DUFO diets compared with the control groups. Rats fed the HF and HFM diets showed normal hemolysis values of $7.6 \%$ and $10.5 \%$, respectively. Protein insufficiency per se caused significantly elevated hemolysis, as seen in the $\mathrm{LF}$ group with a value of $40.5 \%$. However, $\mathrm{RBC}$ hemolysis in DUFO fed rats was 1.5- to 2-fold that of the LF group. The dietary protein level did not change the hemolysis level among the DUFO fed groups.

As can be seen in Table 4, among the seven groups of test rats, only the LU group showed significantly elevated plasma GOT and GPT activities (around 80 $\mathrm{SF} / \mathrm{ml}$ ). In the remaining six groups, the plasma levels of these transaminases were normal $(48-62 \mathrm{SF} / \mathrm{ml})$ and were not significantly different from one another.

Lowered plasma cholesterol and triglyceride concentrations were observed in rats fed DUFO diets compared with their controls. However, the difference was not statistically significant except in the plasma triglycerides of rats fed high protein diets. Rats fed the LF diet had the highest plasma cholesterol and triglyceride levels (Table 4).

The liver lipids and microsomal protein contents are presented in Table 5 . Liver cholesterol concentration was not significantly different in any of the seven groups of rats. However, liver triglyceride concentrations of DUFO fed groups were significantly lower than their controls. The liver total microsomal protein of the HU and HUM groups was significantly higher than that of the HF and HFM groups.

Table 6 presents the results of hepatic aminopyrine $\mathrm{N}$-demethylase (AD) and aniline hydroxylase activities (AH). Compared with the HF group, there was a slight increase in AD of the HU group when the activity is expressed in U/g liver and U/mg protein, although the difference was not statistically significant $(\mathrm{P}>0.05)$. However, when the activity was expressed as U/100 $\mathrm{g}$ body weight, AD of the HU group was 1.8-fold that of the HF group; this difference was statistically significant $(P<0.05)$. The AD activity of the LU group also was significantly higher than that of the HF group, but was lower than that of the HU group.

The elevations of hepatic $\mathrm{AH}$ activity in rats fed DUFO diets were clearly demonstrated in all three enzyme units expressed (Table 6). Compared with the HF and HFM groups, up to $100 \%$ increases of $\mathrm{AH}$ were observed in the HU and HUM groups when the activity was expressed as U/g liver and U/mg protein. About $200 \%$ increases were observed when $\mathrm{AH}$ activ-

\section{TABLE 5}

Hepatic Cholesterol, Triglyceride and Microsomal Protein of Rats Fed $27 \%$ or $8 \%$ Lactalbumin Diet with Fresh or Used Oil for Eight Weeks ${ }^{a}$

\begin{tabular}{|c|c|c|c|c|c|c|}
\hline \multirow[b]{3}{*}{ HF } & \multicolumn{2}{|c|}{ Liver cholesterol } & \multicolumn{2}{|c|}{ Liver triglyceride } & \multicolumn{2}{|c|}{ Microsomal protein } \\
\hline & $\mathrm{mg} / \mathrm{g}$ liver & $\mathrm{mg} /$ liver & $\mathrm{mg} / \mathrm{g}$ liver & $\mathrm{mg} /$ liver & $\mathrm{mg} / \mathrm{g}$ liver & mg/liver \\
\hline & $1.67 \pm 0.61^{\mathrm{a}}$ & $19.37 \pm 7.17^{c}$ & $11.51 \pm 2.45^{\mathrm{c}}$ & $132.68 \pm 30.74^{\mathrm{c}, \mathrm{d}}$ & $95.7 \pm 8.10^{d}$ & $960.4 \pm 131.5^{b}$ \\
\hline $\mathrm{HU}$ & $1.30 \pm 0.51^{\mathrm{a}}$ & $20.76 \pm 9.33^{c}$ & $7.33 \pm 2.62^{\mathrm{a}, \mathrm{b}}$ & $124.49 \pm 37.92^{\mathrm{b}, \mathrm{d}}$ & $95.5 \pm 12.60^{\mathrm{d}}$ & $1365.1 \pm 236.3^{c}$ \\
\hline HFM & $1.52 \pm 0.58^{\mathrm{a}}$ & $18.12 \pm 5.67^{\mathrm{b}, \mathrm{c}}$ & $11.33 \pm 1.70^{\mathrm{c}}$ & $136.22 \pm 14.46^{\mathrm{b}, \mathrm{d}}$ & $80.7 \pm 6.30^{\mathrm{a}, \mathrm{b}}$ & $868.0 \pm 125.3^{\mathrm{b}}$ \\
\hline HUM & $1.24 \pm 0.27^{\mathrm{a}}$ & $19.99 \pm 4.52^{\mathrm{c}}$ & $6.52 \pm 1.71^{\mathrm{a}}$ & $104.23 \pm 24.42^{\mathrm{b}, \mathrm{c}, \mathrm{d}}$ & $93.9 \pm 16.80^{c, d}$ & $1319.4 \pm 240.1^{c}$ \\
\hline LF & $1.24 \pm 0.39^{\mathrm{a}}$ & $9.98 \pm 2.78^{a}$ & $10.53 \pm 3.62^{b, c}$ & $85.28 \pm 26.07^{\mathrm{a}, \mathrm{b}}$ & $75.1 \pm 2.60^{\mathrm{a}}$ & $424.3 \pm 179.7^{\mathrm{a}}$ \\
\hline LU & $1.33 \pm 0.46^{\mathrm{a}}$ & $11.53 \pm 3.86^{\mathrm{a}, \mathrm{b}}$ & $6.05 \pm 3.07^{\mathrm{a}}$ & $51.42 \pm 23.20^{\mathrm{a}}$ & $82.9 \pm 8.56^{a, b, c}$ & $603.0 \pm 94.8^{\mathrm{a}}$ \\
\hline P-HU & $1.17 \pm 0.30^{\mathrm{a}}$ & $14.49 \pm 3.12^{\mathrm{a}, \mathrm{b}, \mathrm{c}}$ & $7.37 \pm 4.32^{\mathrm{a}, \mathrm{b}}$ & $90.63 \pm 47.36^{\mathrm{a}, \mathrm{b}, \mathrm{c}}$ & $90.8 \pm 4.50^{\mathrm{b}, \mathrm{c}, \mathrm{d}}$ & $989.7 \pm 103.4^{\mathrm{b}}$ \\
\hline
\end{tabular}

${ }^{a}$ Each value represents the mean \pm S.D. of six rats.

Values not sharing common superscript letters are significantly different from one another by Duncan's Multiple Range Test $(\mathrm{P}<0.05)$. 
TABLE 6

Hepatic Aminopyrine N-demethylase and Aniline Hydroxylase Activity of Rats Fed $27 \%$ or $8 \%$ Lactalbumin Diet with Fresh or Used Oil for Eight Weeks ${ }^{a}$

\begin{tabular}{|c|c|c|c|c|c|c|}
\hline & \multicolumn{3}{|c|}{ Aminopyrine $\mathrm{N}$-demethylase } & \multicolumn{3}{|c|}{ Aniline hydroxylase } \\
\hline & $\begin{array}{c}\text { Activity/ } \\
\text { body weight } \\
\left(\mathrm{U}^{b} / 100 \mathrm{~g} \mathrm{BW}\right) \\
\end{array}$ & $\begin{array}{c}\text { Tissue } \\
\text { concentration } \\
\times 10^{-3} \\
\left(\mathrm{U}^{b} / \mathrm{g} \text { liver }\right) \\
\end{array}$ & $\begin{array}{c}\text { Specific } \\
\text { activity } \\
\times 10^{-3} \\
\left(\mathrm{U}^{b} / \mathrm{mg} \text { protein }\right) \\
\end{array}$ & $\begin{array}{c}\text { Activity/ } \\
\text { body weight } \\
\left(\mathrm{U}^{c} / 100 \mathrm{~g} \mathrm{BW}\right)\end{array}$ & $\begin{array}{c}\text { Tissue } \\
\text { concentration } \\
\times 10^{-3} \\
\left(\mathrm{U}^{c} / \mathrm{g} \text { liver }\right) \\
\end{array}$ & 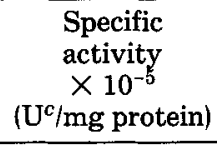 \\
\hline $\mathrm{HF}$ & $0.225 \pm 0.048^{a}$ & $69.17 \pm 14.44^{\mathrm{a}}$ & $0.319 \pm 0.051^{\mathrm{a}}$ & $0.015 \pm 0.009^{a}$ & $4.66 \pm 2.76^{\mathrm{a}}$ & $2.18 \pm 1.41^{\mathrm{a}}$ \\
\hline $\mathrm{HU}$ & $0.391 \pm 0.053^{\mathrm{c}, \mathrm{d}}$ & $82.50 \pm 8.96^{\mathrm{a}}$ & $0.371 \pm 0.058^{a}$ & $0.048 \pm 0.011^{c}$ & $9.98 \pm 2.20^{\mathrm{c}}$ & $4.47 \pm 0.95^{\mathrm{c}}$ \\
\hline HFM & $0.221 \pm 0.027^{\mathrm{a}}$ & $66.33 \pm 6.28^{\mathrm{a}}$ & $0.326 \pm 0.032^{\mathrm{a}}$ & $0.018 \pm 0.005^{\mathrm{a}}$ & $5.33 \pm 1.60^{\mathrm{a}}$ & $2.65 \pm 0.91^{\mathrm{a}, \mathrm{b}}$ \\
\hline HUM & $0.428 \pm 0.046^{\mathrm{d}}$ & $87.17 \pm 10.46^{a}$ & $0.366 \pm 0.087^{a}$ & $0.045 \pm 0.006^{\mathrm{c}}$ & $9.25 \pm 1.12^{\mathrm{b}, \mathrm{c}}$ & $3.88 \pm 0.98^{b, c}$ \\
\hline LF & $0.294 \pm 0.092^{b}$ & $77.50 \pm 17.93^{\mathrm{a}}$ & $0.410 \pm 0.114^{\mathrm{a}}$ & $0.033 \pm 0.008^{b, c}$ & $9.03 \pm 3.17^{\mathrm{b}, \mathrm{c}}$ & $4.75 \pm 1.76^{\mathrm{c}}$ \\
\hline LU & $0.327 \pm 0.040^{\mathrm{b}, \mathrm{c}}$ & $65.67 \pm 12.39^{\mathrm{a}}$ & $0.339 \pm 0.055^{\mathrm{a}}$ & $0.037 \pm 0.010^{\mathrm{b}}$ & $8.11 \pm 2.48^{\mathrm{a}, \mathrm{b}}$ & $3.76 \pm 0.86^{b, c}$ \\
\hline P-HU & $0.376 \pm 0.038^{c, d}$ & $79.83 \pm 7.94^{\mathrm{a}}$ & $0.392 \pm 0.060^{\mathrm{a}}$ & $0.044 \pm 0.007^{\mathrm{c}}$ & $9.33 \pm 1.42^{\mathrm{b}, \mathrm{c}}$ & $4.60 \pm 0.88^{c}$ \\
\hline
\end{tabular}

${ }^{a}$ Each value represents the mean \pm S.D. of six rats.

${ }^{b} \mathrm{U}, \mu \mathrm{mol} \mathrm{HCHO}$ produced/min.

${ }^{c} \mathrm{U}, \mu \mathrm{mol}$ p-aminophenol produced/min.

Values not sharing common superscript letters are significantly different from one another by Duncan's Multiple Range Test $(\mathrm{P}<0.05)$.

ity was expressed as $\mathrm{U} / 100 \mathrm{~g}$ body weight. The $\mathrm{AH}$ activity of the LU group also was significantly lower than that of the $\mathrm{HU}$ group $(\mathrm{P}<0.05)$. Unexpectedly, the activities of $\mathrm{AH}$ and $\mathrm{AD}$ were elevated to a level comparable to the HU or LU group in the LF diet-fed rats.

The hepatic cytochrome P-450 content and NADPHcytochrome $\mathrm{C}$ reductase activity are shown in Table 7 . There were significant increases $(P<0.05)$ in cytochrome P-450 contents in rats fed DUFO diets compared to the fresh oil-fed control groups, especially at the higher protein level. The cytochrome P-450 contents ( $\mathrm{nmol} /$ mg protein) of the $\mathrm{HU}$ and LU groups were $85 \%$ and $27 \%$ higher, respectively, than those of the HF group. In addition, the cytochrome P-450 content was significantly different between the $\mathrm{HU}$ and $\mathrm{LU}$ groups $(\mathrm{P}<0.05)$ when expressed this way. The changes in the activity of hepatic NADPH-cytochrome $\mathrm{C}$ reductase among the test groups were similar to those in cytochrome P-450 content. The enzyme activity was significantly higher in rats fed DUFO diets than that in their control groups. Nevertheless, no significant difference in the activity of this enzyme was observed between the HU and LU groups.

Table 8 presents activities of the two conjugation enzymes, UDP-glucuronyl transferase (UDPGT) and glutathione-S-transferase (GST). Rats fed HU diets had elevated activities of both conjugation enzymes compared to their control. Compared to the HF group, there was also a more than $100 \%$ increase in the UDPGT activity in the LU group, and this increase was significantly higher than that of the HU group when expressed as $\mathrm{U} / 100 \mathrm{~g}$ body weight and $\mathrm{U} / \mathrm{mg}$ protein. In contrast, the increase of UDPGT activity of the HUM group was less than that of the HU group. Again, an unexpected elevation of UDPGT activity in the LF group was noticed. The P-HU group was found to have

\section{TABLE 7}

Hepatic NADPH-Cytochrome C Reductase Activity and Cytochrome P-450 Content of Rats Fed 27\% or 8\% Lactalbumin Diet with Fresh or Used Oil for Eight Weeks ${ }^{a}$

\begin{tabular}{|c|c|c|c|c|c|c|}
\hline \multirow[b]{3}{*}{ HF } & \multicolumn{3}{|c|}{ NADPH-cytochrome $\mathrm{C}$ reductase } & \multicolumn{3}{|c|}{ Cytochrome P-450 } \\
\hline & $\begin{array}{c}\text { Activity/ } \\
\text { body weight } \\
\left(\mathrm{U}^{b} / 100 \mathrm{~g} \mathrm{BW}\right)\end{array}$ & $\begin{array}{c}\text { Tissue } \\
\text { concentration } \\
\left.\text { (U } \mathbf{U}^{b} / \mathrm{g} \text { liver }\right)\end{array}$ & $\begin{array}{c}\text { Specific } \\
\text { activity } \\
\left(\mathrm{U}^{b} / \mathrm{mg} \text { protein }\right)\end{array}$ & $\begin{array}{c}\mathrm{nmol} / \\
100 \mathrm{~g} \mathrm{BW}\end{array}$ & $\begin{array}{c}\text { Tissue } \\
\text { concentration } \\
\text { (nmol/g liver) }\end{array}$ & $\begin{array}{c}\mathrm{nmol} / \mathrm{mg} \\
\text { protein }\end{array}$ \\
\hline & $10.62 \pm 1.73^{\mathrm{a}}$ & $3.25 \pm 0.46^{\mathrm{a}}$ & $0.033 \pm 0.008^{\mathrm{a}}$ & $45.2 \pm 5.5^{\mathrm{a}}$ & $13.92 \pm 2.04^{\mathrm{a}}$ & $0.146 \pm 0.022^{\mathrm{a}}$ \\
\hline HU & $26.59 \pm 4.76^{\mathrm{b}, \mathrm{c}}$ & $5.65 \pm 1.09^{c}$ & $0.060 \pm 0.014^{\mathrm{b}, \mathrm{c}}$ & $122.2 \pm 23.1^{\mathrm{d}}$ & $25.81 \pm 4.42^{\mathrm{b}}$ & $0.270 \pm 0.024^{c}$ \\
\hline HFM & $8.08 \pm 2.75^{\mathrm{a}}$ & $2.35 \pm 0.62^{\mathrm{a}}$ & $0.029 \pm 0.006^{\mathrm{a}}$ & $35.7 \pm 9.3^{\mathrm{a}}$ & $10.82 \pm 3.12^{\mathrm{a}}$ & $0.139 \pm 0.035^{\mathrm{a}}$ \\
\hline HUM & $22.21 \pm 5.88^{\mathrm{b}}$ & $4.50 \pm 1.14^{b}$ & $0.050 \pm 0.017^{b}$ & $122.8 \pm 25.3^{\mathrm{d}}$ & $25.08 \pm 5.64^{\mathrm{b}}$ & $0.267 \pm 0.034^{c}$ \\
\hline $\mathbf{L F}$ & $7.98 \pm 2.49^{\mathrm{a}}$ & $2.37 \pm 0.81^{\mathrm{a}}$ & $0.030 \pm 0.009^{a}$ & $39.6 \pm 12.3^{\mathrm{a}}$ & $11.80 \pm 4.13^{\mathrm{a}}$ & $0.150 \pm 0.045^{a, b}$ \\
\hline $\mathrm{LU}$ & $30.60 \pm 6.49^{c}$ & $5.61 \pm 1.29^{c}$ & $0.066 \pm 0.018^{c}$ & $81.6 \pm 12.3^{\mathrm{b}}$ & $14.88 \pm 2.31^{\mathrm{a}}$ & $0.186 \pm 0.029^{b}$ \\
\hline P-HU & $23.73 \pm 3.58^{\mathrm{b}}$ & $5.04 \pm 0.71^{b, c}$ & $0.056 \pm 0.009^{\mathrm{b}, \mathrm{c}}$ & $103.2 \pm 15.5^{\mathrm{c}}$ & $21.93 \pm 3.31^{\mathrm{b}}$ & $0.242 \pm 0.040^{c}$ \\
\hline
\end{tabular}

${ }^{a}$ Each value represents the mean \pm S.D. of six rats.

${ }^{b} \mathrm{U}, \mu \mathrm{mol}$ cytochrome $\mathrm{C}$ reduced $/ \mathrm{min}$.

Values not sharing common superscript letters are significantly different from one another by Duncan's Multiple Range Test $(\mathrm{P}<0.05)$. 
Hepatic UDP-Glucuronyl Transferase and Glutathione-S-Transferase Activity of Rats Fed 27\% or $8 \%$ Lactalbumin Diet with Fresh or Used Oil for Eight Weeks ${ }^{a}$

\begin{tabular}{|c|c|c|c|c|c|c|}
\hline & \multicolumn{3}{|c|}{ UDP-Glucuronyl Transferase } & \multicolumn{3}{|c|}{ Glutathione-S-Transferase } \\
\hline & $\begin{array}{c}\text { Activity } / \\
\text { body weight } \\
\left(\mathrm{U}^{b} / 100 \mathrm{~g} \mathrm{BW}\right)\end{array}$ & $\begin{array}{c}\text { Tissue } \\
\text { concentration } \\
\left(\mathrm{U}^{b} / \mathrm{g} \text { liver }\right)\end{array}$ & $\begin{array}{c}\text { Specific } \\
\text { activity } \\
\left(\mathrm{U}^{b} / \mathrm{mg} \text { protein) }\right.\end{array}$ & $\begin{array}{c}\text { Activity/ } \\
\text { body weight } \\
\left(\mathrm{U}^{c} / 100 \mathrm{~g} \mathrm{BW}\right)\end{array}$ & $\begin{array}{c}\text { Tissue } \\
\text { concentration } \\
\text { (U⿺辶) }\end{array}$ & $\begin{array}{c}\text { Specific } \\
\text { activity } \\
\text { (U } \mathrm{U}^{c} / \text { mg protein) }\end{array}$ \\
\hline HF & $0.33 \pm 0.12^{\mathrm{a}}$ & $0.101 \pm 0.033^{\mathrm{a}}$ & $0.485 \pm 0.208^{a}$ & $2.52 \pm 0.63^{a, b}$ & $0.79 \pm 0.25^{b, c}$ & $3.78 \pm 1.30^{b, c}$ \\
\hline $\mathrm{HU}$ & $0.98 \pm 0.21^{c}$ & $0.203 \pm 0.045^{b, c}$ & $0.930 \pm 0.181^{b, c}$ & $5.53 \pm 2.09^{c}$ & $1.20 \pm 0.39^{\mathrm{d}}$ & $5.34 \pm 2.10^{\mathrm{d}}$ \\
\hline HFM & $0.32 \pm 0.17^{\mathrm{a}}$ & $0.096 \pm 0.051^{\mathrm{a}}$ & $0.477 \pm 0.272^{\mathrm{a}}$ & $2.34 \pm 0.95^{\mathrm{a}, \mathrm{b}}$ & $0.70 \pm 0.26^{b, c}$ & $3.47 \pm 1.50^{a, b, c}$ \\
\hline HUM & $0.68 \pm 0.21^{b}$ & $0.139 \pm 0.043^{\mathrm{a}}$ & $0.573 \pm 0.191^{\mathrm{a}}$ & $7.19 \pm 3.19^{\mathrm{d}}$ & $1.40 \pm 0.60^{\mathrm{d}}$ & $5.52 \pm 3.40^{\mathrm{d}}$ \\
\hline LF & $0.71 \pm 0.21^{b}$ & $0.207 \pm 0.064^{b, c}$ & $1.073 \pm 0.365^{\mathrm{c}, \mathrm{d}}$ & $1.51 \pm 0.39^{\mathrm{a}}$ & $0.44 \pm 0.10^{\mathrm{a}}$ & $2.27 \pm 0.75^{\mathrm{a}}$ \\
\hline LU & $1.28 \pm 0.25^{\mathrm{d}}$ & $0.230 \pm 0.051^{\mathrm{c}}$ & $1.245 \pm 0.328^{\mathrm{d}}$ & $3.08 \pm 1.19^{b}$ & $0.55 \pm 0.20^{\mathrm{a}, \mathrm{b}}$ & $2.75 \pm 0.93^{a, b}$ \\
\hline P-HU & $0.71 \pm 0.15^{b}$ & $0.152 \pm 0.029^{b}$ & $0.756 \pm 0.146^{a, b}$ & $4.40 \pm 0.76^{\mathrm{c}}$ & $0.93 \pm 0.15^{\mathrm{c}}$ & $4.41 \pm 0.67^{c, d}$ \\
\hline
\end{tabular}

${ }^{a}$ Each value represents the mean \pm S.D. of six rats.

${ }^{b} \mathrm{U}, \mu \mathrm{mol}$ p-nitrophenol decreased/min.

${ }^{c} \mathrm{U}, \mu \mathrm{mol} \mathrm{p}$-nitrobenzyl chloride decreased/min.

Values not sharing common superscript letters are significantly different from one another by Duncan's Multiple Range Test $(\mathrm{P}<0.05)$.

lower UDPGT activity than the HU and LU groups, but the difference was significant $(P<0.05)$ only for $\mathrm{U} / 100 \mathrm{~g}$ body weight.

Different trends were observed in the effect of dietary treatment on GST activity. The GST activity of the HUM group surpassed all the remaining six groups numerically. When the activity of GST was expressed as $\mathrm{U} / 100 \mathrm{~g}$ body weight, it was significantly higher in the HUM group than in the HU group. The GST activity of the LU group was significantly lower than that of the HU group but was not significantly different from that of the HF group. Furthermore, the LF group had the lowest level of GST activity among the seven groups tested. When expressed as U/g liver and U/mg protein, the GST activity of the LF group was significantly lower than that of the HF group.

As for the P-HU group, their feed efficiency, apparent digestibility, relative liver weight, plasma cholesterol and triglyceride, plasma GOT and GPT, hematocrit, liver cholesterol and triglyceride, liver microsomal protein, $\mathrm{AD}, \mathrm{AH}$ NADPH-cytochrome $\mathrm{C}$ reductase activities were not significantly different from those parameters of the HU group. Their liver cytochrome P-450 content and GST activity were slightly lower than those of the HU group, but higher than those of the LU group; the differences were significant for $\mathrm{nmol} / 100 \mathrm{~g}$ body weight (cytochrome P-450) and $\mathrm{U} / \mathrm{g}$ liver (GST activity).

\section{DISCUSSION}

In our preliminary experiment, it was found that the mortality of rats in the LU group, which were fed the LU diet immediately after weaning, was as high as $75 \%$ within eight weeks of feeding. However, in the present study, weanling rats were fed stock diet for one week before they were put on test diets, and no death (only mild diarrhea) was observed.

The deleterious effects resulting from DUFO feeding were minimal when rats consumed a high protein diet concomitantly. The feed efficiency of the HU groups was comparable to the high protein fresh oil control group, suggesting that rats in the HU group retained nearly normal nutrient utilization and metabolism. In contrast, toxicity of DUFO was augmented by dietary protein insufficiency. Body weight gain and feed efficiency were significantly depressed. The results confirm the beneficial effects of a high protein diet on the toxicity of DUFO (6,7).

Poor lipid digestion and absorption of DUFO were served in this study and others $(2,3)$. This could be attributed to the poor absorbability of the secondary products of oxidized lipid, especially polymeric materials $(2,3)$. Kanazawa et al. found that half of the orally administered ${ }^{14} \mathrm{C}$-linoleic acid autoxidation secondary products were excreted in feces of rats (32). The DUFO sample used in this study had a low peroxide value and high viscosity, indicating a rich content of secondary products, especially polymeric compounds.

The primary products of lipid oxidation, namely peroxides and hydroperoxides, are highly toxic to animals when administered parenterally (33-35). However, oral administration of lipid hydroperoxides is considerably less toxic, probably due to low absorbability $(32,36,27)$ or to some conversion occurring before or during the absorption process (38).

On the other hand, secondary products such as polymers (39), aldehydes $(40,41)$, hydroperoxyalkenals (42) and hydroperoxyepoxides (43) have been shown to be toxic to animals, tissues or biomolecules. In one study (32), half of the absorbed dose was excreted in the urine, $25 \%$ in expired carbon dioxide, and $2.6 \%$ accumulated in the liver caused increased liver peroxidation, liver hypertrophy and elevated serum transaminase activity. The report of Oarada et al. (44) showed that among the oil autoxidation products, the low molecular weight fraction was absorbed more easily and metabolized faster than the polymeric fraction. Both authors suggested that aldehyde compounds are the major contributors to toxicity and that the liver is the major site of metabolism. 
Among the mixed-function oxidase activities induced by DUFO in this study, aniline hydroxylase significantly surpassed aminopyrine $\mathrm{N}$-demethylase. Andia and Street (5) also observed a greater increase in EPN oxidation than in demethylation in rats fed thermally oxidized fat. The results suggest that the hydroxylation reaction is more important than demethylation in the metabolism of oxidation products of DUFO. This seems to be reasonable because lipid oxidation products are generally not abundant in the methyl group.

In the present study, we found the cytochrome P-450 content, NADPH-cytochrome $\mathrm{C}$ reductase, mixed function oxidase, UDP-glucuronyl transferase and glutathione S-transferase activities all are markedly elevated by the feeding of DUFO. The results further suggest that hydroxylation, oxidation and conjugation reactions might be important steps in the metabolism of oxidation products of DUFO.

The induction of mixed function oxidase, cytochrome P-450 content and glutathione-S-transferase activities by DUFO were considerably restricted by feeding a low protein diet in the present study. This is in agreement with the depression of mixed function oxidase and the cytochrome P-450 system in rats fed a low protein diet with $(12-14)$ or without $(8-10)$ the presence of an inducer. On the other hand, the induction of NADPH-cytochrome $\mathrm{C}$ reductase and UDPglucuronyl transferase activities by DUFO were not affected by dietary protein insufficiency. The cosubstrates of these latter two enzymes, NADPH and glucuronate, are derived from carbohydrate intermediary metabolism. Because an ample supply of carbohydrate is available in a low protein diet, these two reactions might account for the major biotransformation pathway for lipid oxidation products in rats fed a low protein diet. Significantly increased liver UDP. glucuronyl transferase has been reported in rats fed a protein-free diet (45). Nevertheless, rats fed the LU diet showed significantly increased SGOT and SGPT activities, suggesting that insufficient induction of liver enzymes might cause liver damage in these rats. In contrast, the observations made on the P-HU group indicated that the reduction of food intake exerted much less effect on the liver microsomal enzyme inducibility. The significant decrease of the UDPGT activity in the P-HU group might be related to the inadequacy of energy, especially carbohydrate, due to food restriction.

Dietary protein level and supplementation of methionine exerted profound effects on liver glutathione S-transferase activity in this study. Protein insufficiency severely depressed the activity of this enzyme, whether animals were fed DUFO or not. In high protein and DUFO fed rats, supplementation of methionine further enhanced the activity of GSH S-transferase. Among all the parameters measured in this study, this is the only one which is significantly influenced by methionine supplementation. Glutathione, the cosubstrate of this enzyme, plays an important role in the defense mechanisms against free radical mediated lipid peroxidation (46). Dietary supplementation of sulfurcontaining amino acids significantly increases tissue glutathione level and decreases toxicity of certain chemi- cals in an animal body (47). Denekes et al. reported an increased oxygen toxicity in rats fed a low protein diet, which could be alleviated by supplementation of $S-$ amino acids through the elevation of tissue glutathione concentration $(48,49)$. In addition to the increase of GSH S-transferase, we also observed a decrease in UDP-glucuronyl transferase in the HUM group. This probably suggests that glutathione conjugation might be a preferential pathway for biotransformation in rats fed a DUFO and methionine supplemented high protein diet.

Using fractionated oil autoxidation products to incubate normal rat RBC in vitro, Yoshioka and Kaneda (50) found that $11,0.037,4.3$ and $8.7 \mu \mathrm{mol}$, respectively, of methyl linoleate hydroperoxide, hydroperoxyalkenal, hydroxyalkenal and alkenal, were required to produce $50 \%$ hemolysis. In another study, they also observed a $24.9 \% \mathrm{RBC}$ in vitro hemolysis in rats fed a 21-day autoxidation product of methyl linoleate (51). The autoxidized sample they used had a low peroxide value and showed high toxicity, suggesting that secondary products were responsible for the toxicity (51).

Vitamin E deficiency symptoms, such as encephalomalacia in chicks (52), and creatinuria and red cell hemolysis in rabbits (53), were observed in animals infused with methyl linoleate hydroperoxide. Therefore, both primary and secondary products of lipid oxidation in DUFO could be the causative factors for the increased hemolysis observed in the present study.

On the other hand, in vitro RBC hemolysis is recognized as a criterion for vitamin $E$ status. In the present study, the dietary vitamin E supplement from the vitamin premix is marginal (54), i.e., $20 \mathrm{mg} \mathrm{dl}-\alpha$ tocopheryl actate/kg diet, in the PUFA content. However, normal hemolysis (less than $10 \%$ ) was observed in the HF and HFM groups. This could be attributed to the significant amount of vitamin $\mathrm{E}$ contributed by the fresh soybean oil in these diets (55). Concerning the vitamin $\mathrm{E}$ status, there are two possibilities for the elevation of red cell hemolysis in DUFO fed rats. First, the actual vitamin $E$ intake of these rats was reduced because vitamin $E$ in fresh soybean oil was destroyed during the frying process (56); second, the vitamin $\mathrm{E}$ requirement of DUFO fed rats was increased as a result of increased lipid peroxidation. Oral administration of methyl linoleate hydroperoxide was shown to increase tissue TBA reactive substance (57).

The microsomal cytochrome P-450 enzyme system is known to be involved in the generation of free radicals and the enhancement of lipid peroxidation (58). Whether the raised level of the cytochrome P-450 enzyme system or the absorbed lipid oxidation products of DUFO was responsible for the increased lipid peroxidation could not be answered in the present study.

An unexpected finding in this study is the raised level of liver mixed function oxidase, UDP-glucuronyl transferase and RBC hemolysis in rats fed a low protein fresh oil diet, compared to rats fed a high protein fresh oil diet. Normal defense mechanisms against in vivo lipid peroxidation, including antioxidants (such as vitamin E) and detoxification enzymes, (such as superoxide dismutase, catalase and glutathione peroxidase), act in concert as cellular free radical and peroxides scavengers (59). It has been reported that 
superoxide dismutase was signifcantly depressed in rats fed a $3 \%$ casein diet (48). Another study showed a decreased catalase activity in rats fed a protein-free diet (49). Insufficiency in these enzyme activities together with marginal vitamin $\mathrm{E}$ supply in the LF diet might result in abnormal defense mechanisms against in vivo lipid peroxidation when they received a high level of PUFA from $15 \%$ fresh soybean oil in the diet. Further experimentation is needed to support this view.

When rats were fed a high protein diet, feeding of deteriorated used frying oil resulted in more than twofold increases in liver aniline hydroxylase, cytochrome P-450 system and conjugation enzymes. Feeding a low protein diet significantly restricted the elevation of aniline hydroxylase, cytochrome P-450 content and glutathione S-transferase activities in response to deteriorated used frying oil, resulting in significantly increased serum transaminase activities. Other effects of deteriorated oil were the decreased fat absorption and increased RBC in vitro hemolysis, neither of which were influenced by dietary protein levels.

\section{ACKNOWLEDGMENT}

This study was supported by Grant NSC 75-0409-B002-33 from the National Science Council, Republic of China.

\section{REFERENCES}

1. Artman, N.R., Adv. Lipid Res. 7:245 (1969).

2. Nolen, G.A., J.C. Alexander and N.R. Artman, J. Nutr. 93:337 (1967).

3. Poling, C.E., E. Eagle, E.E. Rice, A.M.A. Durand and M. Fisher, Lipids 5:128 (1970).

4. Miller, J., and D.R. Landes, J. Food Sci. 40:545 (1975).

5. Andia, A.B., and J.C. Street, J. Agric. Food Chem. 23:173 (1975).

6. Hemans, C., F. Kummerow and E.G. Perkins, J. Nutr. 103:1665 (1973).

7. Chen, M.H., M.J. Shieh, R.L. Chang and Y.C. Tsai, J. Chinese Nutr. Soc. 8:21 (1983).

8. Mgbodile, M.U.K., and T.C. Campbell, J. Nutr. 102:53 (1972).

9. Campbell, T.C., and J.R. Hayes, Fed. Proc. 35:2470 (1976).

10. Hayes, J.R., M.U.K. Mgbodile, A.H. Merrill Jr., L.S. Nerurkar and T.C. Campbell, J. Nutr. 108:1788 (1978).

11. Kato, R., T. Oshima and S. Tomizawa, Jpn. J. Pharmacol. 18:356 (1968).

12. Kato, N., T. Tani and A. Yoshida, J. Nutr. 110:16865 (1980).

13. Hayes, J.R., M.U.K. Mgbodile and T.C. Campbell, Biochem. Pharmacol. 22:1005 (1973).

14. Marshall, W.J., and A.E.M. McLean, Ibid. 18:153 (1969).

15. Kato, N., and A. Yoshida, Agric. Biol. Chem. 43:191 (1979).

16. Official and Tentative Methods of The American Oil Chemists' Society, 3rd edn., edited by E.M. Sallee, AOCS, Champaign, IL, 1971, Methods cd 3a-63 and 8-53.

17. Michael, J.F., and P.A.T. Swoboda, J. Sci. Fd. Agric. 28:387 (1977).

18. Horwitt, M.K., C.C. Harvey, G.D. Duncan and W.C. Wilson, Am. J. Clin. Nutr. 4:408 (1956).

19. Franey, R.J., and E. Amador, Clin. Chim. Acta. 21:255 (1968).

20. Megraw, R.E., D.E. Dunn and H.G. Biggs, Clin. Chem. $25: 273$ (1979).

21. Reitman, S., and S. Frankel, Am. J. Clin. Path. 28:56 (1957).

22. Fujita, T., and G.J. Mannering, J. Biol. Chem. 248:8150 (1973).

23. Nash, T., J. Biochem. 55:416 (1953).
24. Thurman, R.G., L.A. Reinke, S. Belinsky, R.K. Evans and F.C. Kauffman, Arch. Biochem. Biophys. 209:137 (1981).

25. Habig, W.H., M.J. Pabst and W.B. Jacoby, J. Biol. Chem. 249:7130 (1974).

26. William, C.H., and H.J. Kamin, Ibid. 237:587 (1962).

27. Omura, T., and R. Sato, Ibid. 239:2370 (1964).

28. Lowry, O.H., N.J. Rosebrough, A.L. Farr and R.J. Randall, Ibid. 193:265 (1951).

29. Folch, J., M. Lees and G.H. Sloane Stanley, Ibid. 226:497 (1957).

30. Abell, L.L., B.B. Levy, B.B. Brodies and F.E. Kendall, Ibid. 95:357 (1952).

31. Kim, J., and F.J. Kohout, in SPSS: Statistical Package for the Social Sciences, 2nd edn., edited by N.H. Nie, C.H. Hull, J.G. Jenkins, K. Steinbrenner and D.H. Bent, McGraw-Hill Co., New York, 1975, pp. 398-430.

32. Kanazawa, K., E. Kanazawa and M. Natake, Lipids 20:412 (1985).

33. Horgan, V.J., J.S.L. Philpot, B.W. Poter and D.B. Roodyn, Biochem. J. 67:551 (1957).

34. Olcott, H.S., and A. Dolev, Proc. Soc. Exp. Biol. Med. 114:820 (1963).

35. Findlay, G.M., H.H. Draper and J.G. Bergan, Lipids 5:971 (1970).

36. Nakatsugawa, K., and T. Kaneda, Yukagaku (J. Jpn. Oil Chem. Soc.) 32:361 (1983).

37. Nakatsugawa, K., and T. Kaneda, Ibid. 30:74 (1980).

38. Bergan, J.G., and H.H. Draper, Lipids 5:977 (1970).

39. Kaunitz, H., C.A. Slanetz, R.E. Johnson, H.B. Knight, D.H. Saunders and D. Swern, J. Am. Oil Chem. Soc. 33:630 (1956).

40. Kanazawa, K., G. Danno and M. Natake, J. Nutr. Sci. Vitaminol 21:373 (1975).

41. Sumerfield, F.W., and A.L. Tappel, Biochim. Biophys. Acta $740: 185$ (1983).

42. Yoshioka, M., and T. Kaneda, Yukagaku (J. Jpn. Oil Chem. Soc.) 23:321 (1974).

43. Imagawa, T., S. Kasai, K. Matsui and T. Nakamura, $J$. Biochem. 94:87 (1983).

44. Oarada, M., T. Miyazawa and T. Kaneda, Lipids 21:150 (1986).

45. Woodcock, B.G., and G.C. Wood, Biochem. Pharmacol. 20:2703 (1971).

46. Meister, A., Science 220:472 (1983).

47. Reed, D.J., and P.W. Beatty, Rev. Biochem. Toxicol. 2:213 (1980).

48. Denekes, S.M., S.N. Gershoff and B.L. Fanburg, J. Appl. Physiol: Respirat. Environ. Exercise Physiol. 54:147 (1983).

49. Denekes, S.M., B.A. Lunch and B.L. Fanburg, J. Nutr 115:726 (1985).

50. Yoshioka, M., and T. Kaneda, Yukagaku (J. Jpn. Oil Chem. Soc.) 23:41 (1974).

51. Yoshioka, M., K. Tachibana and T. Kaneda, Ibid. 23:327 (1974).

52. Nishida, T., H. Tsuchiyama, M. Inoue and F.A. Kummerow, Proc. Soc. Exp. Biol. Med. 105:308 (1960).

53. Kokatnur, M.G., J.G. Bergan and H.H. Draper, Ibid. 123:254 (1966).

54. Bieri, J.G., Ann. N.Y. Acad. Sci. 203:181 (1972)

55. Bieri, J.G., and R.P. Evarts, J. Am. Diet. Assoc. 66:134 (1975).

56. Giani, E., I. Masi and C. Galli, Lipids 20:439 (1985).

57. Miyazawa, T., A. Nagaoka and T. Kaneda, Agric. Biol. Chem. 47:1333 (1983).

58. Earnster, L., K. Nordenbrand and S. Orrenius, in Lipid Peroxides in Biology and Medicine, edited by K. Yagi, Academic Press, Florida, 1982, pp. 55-79.

59. Chow, C.K., Am. J. Clin. Nutr. 37:1066 (1979).

[Received October 20, 1987; accepted April 15, 1988] 